\title{
EXISTENCIAS ABYECTAS EN EL REGISTRO FOTOGRÁFICO DE LARIZA HATRICK: HACIA UNA RECUPERACIÓN DE LA ALTERIDAD RADICAL
}

\author{
Ariel Martínez \\ Universidad Nacional de La Plata \\ amartinez@psico.unlp.edu.ar
}

\section{RESUMEN}

El presente artículo se propone reflexionar en torno a aquella franja poblacional abyecta e ininteligible a partir de algunas expresiones del itinerario fotográfico de la artista y activista argentina (platense) Lariza Hatrick. Aunque sus retratos plasman momentos cotidianos de existencias maricas, lesbianas y travestis, afirmamos que lo relevante de su producción visual refiere a la posibilidad de suscitar una alteridad radical que trasciende las nominaciones identitarias que las taxonomías modernas ofrecen como única forma de distribuir reconocimiento. Al reseñar algunas fotografías de Shirley Bombón (trava sudaca) se enfatiza la necesidad de transversalizar la perspectiva queer con una dimensión cuir: un intento de rescatar la dimensión crítica más allá del límite que impone la positividad de los significados lingüísticos. Se afirma que las producciones artísticas son capaces de sugerir la potencia de aquello inarticulable, zona indispensable para la actitud de revuelta y para la creación de lo radicalmente nuevo.

Palabras Clave: Lariza Hatrick, cuir, alteridad radical, fotografía, abyección.

\section{ABJECT EXISTENCES IN LARIZA HATRICK'S PHOTOGRAPHIC REGISTRY: TOWARDS A RECOVERY OF RADICAL ALTERITY}

\section{Abstract}

This article aims to reflect on that abject and unintelligible population strip based on some expressions of the photographic itinerary of the Argentine artist and activist (from La Plata) Lariza Hatrick. Although her portraits capture daily moments of queer, lesbian and transvestite existence, we affirm that the relevance of her visual production refers to the possibility of arousing a radical alterity that transcends the identity nominations that modern taxonomies offer as the only way to distribute recognition. By reviewing some photographs by Shirley Bombón (trava sudaca) it emphasizes the need to mainstream the queer perspective with a cuir dimension: an attempt to rescue the critical dimension beyond the limit imposed by the positivity of linguistic meanings. It is affirmed that artistic productions are capable of suggesting the power of the inarticulable, an indispensable area for the attitude of revolt and for the creation of the radically new.

KEYWORDs: Lariza Hatrick, cuir, radical alterity, photography, abjection.

DOI: https://doi.org/10.25145/j.clepsydra.2021.21.10

Revista Clepsydra, 21; marzo 2021, pp. 203-229; ISSN: e-2530-8424 


\section{INTRODUCCIÓN: ALGUNAS COORDENADAS GENERALES}

¿Cómo y por qué diversas personas llegan a pensarse a sí mismas como miembros de un grupo con un pasado compartido? Ante este interrogante partimos del siguiente problema: sólo se vuelven inteligibles $-\mathrm{y}$, por lo tanto, capaces de pensarse a sí mismos mediante elementos simbólicos colectivos, con mayores o menores grados de legitimidad-aquellos sujetos localizados dentro del ámbito normativo que confiere reconocimiento. La producción de memoria social se inscribe dentro de los términos simbólicos hegemónicos En este sentido, es preciso diferenciar aquellas localizaciones de sujeto que, con mayor o menor grado de legitimidad, pertenecen al campo de lo inteligible de aquellas otras que caen por fuera de los marcos de reconocimiento y, por tanto, devienen existencias ininteligibles o abyectas. Así, guardan especial potencia disruptiva aquellas existencias que configuran una alteridad radical respecto al orden simbólico cisheteronormado y se alejan del constructo de lo Otro - es decir, del reconocimiento otorgado por los términos de las taxonomías identitarias con las que contamos-.

Como forma de abordar la relevancia y el reconocimiento de esta alteridad radical vinculada con las existencias abyectas, ofrecemos un material visual sugerente: algunas expresiones del itinerario fotográfico de la militante lesbiana argentina Lariza Hatrick (nacida el 9 de marzo de 1980). Para realizar algunas observaciones al respecto partimos de postulados fundamentales de la teoría queer en la versión de Judith Butler, aunque proponemos la importancia de anclar, dialogar y cuestionar tales aportes a partir de expresiones artísticas locales, puesto que estas son capaces de sugerir el carácter abyecto que interesa señalar. Denominamos como perspectiva cuir a esta aproximación estética local y contextuada, capaz de esbozar la alteridad radical resonante en todos aquellos que caen por fuera de lo nominable.

Judith Butler se aproxima al interrogante del que partimos. Teoriza la forma en que opera un sistema normativo denominado matriz de inteligibilidad heterosexual:

Utilizo la expresión matriz heterosexual [...] para designar la rejilla de inteligibilidad cultural a través de la cual se naturalizan cuerpos, géneros y deseos. He partido de la idea de 'contrato heterosexual' de Monique Wittig y, en menor grado, de la idea de 'heterosexualidad obligatoria' de Adrienne Rich para describir un modelo discursivo/epistémico hegemónico de inteligibilidad de género, el cual da por sentado que para que los cuerpos sean coherentes y tengan sentido debe haber un sexo estable expresado mediante un género estable (masculino expresa hombre, femenino expresa mujer) que se define históricamente y por oposición mediante la práctica obligatoria de la heterosexualidad (Butler, El género 292).

Es claro que no todas las existencias logran cumplir con los principios de inteligibilidad, por lo tanto no todas logran articularse simbólicamente como auténticas, legítimas o como ilegítimas. Así, el campo normativo produce una línea abisal que separa un centro normativo, habitado por aquellos sujetos inteligibles de acuerdo con las exigencias de la matriz heterosexual, respecto de una periferia habitada por aquellas identidades inteligidas mediante identidades patologizadas, inferiorizadas 
y excluidas. Como ya se ha mencionado, interesa establecer un matiz al respecto. Tanto lo legítimo como lo ilegítimo es inteligible bajo los términos de la matriz cisheterosexual. Por lo tanto, los intentos de hacer legítimo lo ilegítimo impiden la transformación radical del campo normativo, puesto que hacen rodar los mismos términos que articulan el reconocimiento.

Por este motivo nos resulta de mayor interés aludir al estatuto ontológico y político de otra franja poblacional, cuyas existencias sufren un grado de exclusión radical y, así, caen por fuera de la matriz de inteligibilidad heterosexual. Se trata de una alteridad localizada más allá de toda inscripción simbólica y, por lo tanto, de las representaciones que configuran los marcos sociales hegemónicos de memoria. Aunque no es capaz de llevarlo hasta sus últimas consecuencias, la propia Judith Butler propone un término que sugiere tal grado de ininteligibilidad: lo abyecto. A partir del pensamiento de Julia Kristeva, Butler sugiere figuras corporales y subjetivas que no caben en ninguno de los términos, categorías o taxonomías normativas. Estas existencias conforman el campo de lo deshumanizado y lo abyecto contra lo cual se conforma la definición de lo humano. El campo simbólico, nos dice Kristeva, requiere como gesto fundacional el establecimiento de límites que, por medio de la exclusión, configuran una diferencia constitutiva (Kristeva 9). Lo abyecto nombra algo difícilmente articulable bajo los términos del lenguaje y su carga normativa, aquello que ha sido expulsado, evacuado como excremento, literalmente convertido en un grado de otredad que se torna alteridad radical. Las existencias espectrales circulantes en estos intersticios de la matriz producen marcas que es preciso recuperar para reconstruir vidas concretas, aunque no ya bajo los términos de los marcos hegemónicos de memoria colectiva, sino en sus propios términos - aquellos donde la alteridad constituye sus manifestaciones escénicas imposibles de ser representadas mediante el lenguaje (Martínez y Mora 4)-. ¿Cómo y por qué llegamos a pensarnos como miembros de un grupo con un pasado compartido? Pues compartimos los sentidos hegemónicos a partir de los cuales configuramos nuestras identidades.

La mirada cuir concibe las existencias abyectas de forma concreta y situada. Considerar lo queer de forma abstracta y descontextualizada amenaza paradójicamente la potencia crítica de sus propios postulados. Susan Stryker enfatiza la importancia de considerar la

diferencia encarnada y cómo esas diferencias se transforman en jerarquías sociales, sin perder de vista el hecho de que 'diferencia' y 'jerarquía' nunca son meras abstracciones; son sistemas de poder que operan en cuerpos reales, capaces de producir dolor y placer, salud y enfermedad, castigo y recompensa, vida y muerte (Stryker 3).

Este artículo considera una propuesta estético-disidente local, que presentamos como una operación política de memoria, a la que denominaremos cuir ${ }^{1}$. Así,

${ }^{1}$ Desde nuestra perspectiva, adoptar una perspectiva cuir no implica abandonar cualquier marco teórico proveniente de usinas hegemónicas de producción de conocimiento (localizadas en el norte global). La incorporación de intelectuales locales no garantiza tal vuelco epistemológico capaz 
a partir del itinerario fotográfico de la artista local argentina se extraen reflexiones que nos permiten avanzar en un grado de radicalidad crítica mayor que algunas de las afirmaciones del pensamiento queer (norteamericano). Es sabido que el norte global queer constituye una caja de resonancia que indefectiblemente nos impone las categorías conceptuales a partir de las cuales pensamos las disidencias y los sistemas normativos. Para retener la potencia crítica de las herramientas teóricas queer es necesario cuirizar esos saberes mediante la resistencia crítica desde los sures. Las recepciones y apropiaciones subversivas son un requerimiento para someter a crítica la marca geopolítica de teorías provenientes del norte -en tanto centro hegemónico-. Así, propuestas escénicas locales disidentes posibilitan la tensión de categorías teóricas queer. Esta tensión nos obliga a examinar y reescenificar la letra abstracta de los conceptos a los que recurrimos. Así, cuirizar lo queer pone en danza la dinámica crítica que destotaliza cualquier pretensión unitaria, incluso, paradójicamente, de la teoría queer. La misma Butler afirmó que «normalizar lo queer sería, después de todo, su triste final» (Butler, Against 21).

\section{EL REGISTRO FOTOGRÁFICO CUIR DE LARIZA HATRICK}

Lariza Hatrick, activista lesbiana y sudaca, ha construido un archivo foto-

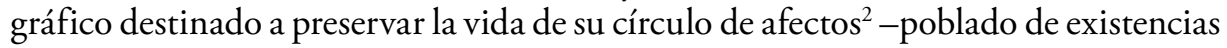
no legitimadas por la cisheteronorma-. En su Instagram se autodenomina bloodlariza y se describe como «lesbiana wittiguiana no binaria tercer mundista» y connota su fotografía como «imágenes lesbianas disidentes a la norma cisheterosexual $»^{3}$. Su militancia y activismo sostenido desde hace más de quince años en la localidad de La Plata (Buenos Aires, Argentina) la convierten en una referencia para quienes habitan los territorios sexodisidentes y se autodenominan genéricamente como Mostris -en alusión a una exaltación no peyorativa de la monstruosidad disidente-. Su fotografía retrata y cristaliza sus afectos en medio del fracaso y la abyección. Para

\footnotetext{
de subvertir miradas hegemónicas (aun dentro del campo de los estudios queer). Apostamos por la potencia de tensar las categorías teóricas con las que contamos con propuestas estético-políticas locales. No podemos pensar por fuera de las categorías imperantes -independientemente del lugar geopolítico de su producción- pero sí podemos someter a escrutinio crítico tales categorías a partir de expresiones estéticas situadas que emergen de los sures epistemológicos, por un lado, y que muestran una dimensión excesiva y no reductible a las fronteras restrictivas que instala la representación lingüística.

2 A partir de diálogos personales con Lariza Hatrick que han recorrido múltiples tópicos, este trabajo recoge su punto de vista respecto a las disidencias cuir, el registro fotográfico y la militancia política. También, debido a sus resonancias, se entrecruza la mirada situada de la fotógrafa con algunas referencias del pensamiento queer antisocial. Se intenta construir un punto de vista epistemológico que resitúe el lugar de la memoria en la recuperación de aquellas existencias abyectas. La irrupción del registro fotográfico de la vida de Shirley Bombón, interpretado desde el marco epistémico-político ofrecido, opera como eje transversal de este recorrido.
}

${ }^{3}$ https://www.instagram.com/bloodlariza/?hl=es-la. 
Hatrick estas vidas, y su propia vida, no son menos valiosas pese al significado de marginalidad y fracaso que adquieren para el afuera.

Hatrick se preocupa por evitar los circuitos hegemónicos ${ }^{4}$. El (escaso) reconocimiento de su propuesta seguramente se debe a su retórica fotográfica rebelde, pues no busca consolidar un proyecto queer legitimado académica y políticamente. Su registro es capaz de atravesar y cuestionar, paradójicamente, los requerimientos que actualmente gravitan en torno a la 'fotografía queer'. El innumerable cúmulo de fotografías interesadas en retratar existencias no hegemónicas atestigua la compleja red político-afectiva en la que se mueve Hatrick. Sus registros fotográficos señalan una profunda subversión estético-política al elidir los parámetros normativos a partir de los cuales se adjudican las identidades. Nos interesa sugerir claves teórico-epistemológicas que dialogan con las fotografías ${ }^{5}$ de Hatrick en términos del profundo interés por trazar políticas que anudan de forma compleja alteridad y memoria. Las fotografías seleccionadas retratan a Shirley Bombón, una trava sudaca que forma parte de la red vincular de nuestra fotógrafa ${ }^{6}$. Los retratos de Shirley Bombón son una ocasión para reflexionar sobre las luchas contra el olvido de una vida, también sobre las formas en que las militancias y registros disidentes operan como formas particulares de rescate vinculadas con la concepción de alteridad que ofrecemos. Esta aproximación permite priorizar y recuperar epistemológicamente aquel registro capaz, en su negatividad, de perturbar la coherencia identitaria y la consecución de los principios de inteligibilidad que clasifican los cuerpos mediante la imposición de fronteras identitarias (De Lauretis 78, Edelman 21).

Hatrick insiste en recuperar la multiplicidad y socavar las sedimentaciones culturales que organizan, en nuestra mirada, el campo de lo visible y lo recuperable mediante los marcos normativos que construyen la memoria colectiva. Sólo así podremos retratar las identidades y los cuerpos del modo en que Hatrick nos propone. La película analógica de $35 \mathrm{~mm}$ en color que utiliza no se ciñe a las pretensiones técnicas, ni a la construcción impostada de situaciones. Lo que podría entenderse como una falta de atención a la composición fotográfica forma parte de la declaración política que subvierte los parámetros estéticos convencionales. La fotógrafa se propone capturar la alteridad radical que habita en el mundo, y esta no se ciñe al carácter transgénero de las personas fotografiadas -que, en tanto que identidades, aún muestran demasiada proximidad con la matriz normativa-. La valencia cuir de sus retratos, en algunas ocasiones grotescos y bizarros, reside en su intención de

${ }^{4}$ De aquí en más, todas las afirmaciones referidas a Lariza Hatrick corresponden a registros de comunicaciones personales.

${ }^{5}$ Algunas de las fotografías que se utilizan para este ensayo se encuentran publicadas en el Instagram de Lariza Hatrick, aunque la mayor parte de ellas pertenecen a su archivo personal.

${ }^{6}$ De Shirley Bombón se sabe, a partir de sus relatos, que nació en Lima (Perú) el 20 de julio de 1957. A los veinte años viajó a Europa. Durante dos décadas vivió en Italia, Alemania y España. Luego de su regreso a Perú viajó a la Argentina, donde fue detenida. Una vez libre vivió allí sus últimos años y se convirtió en una referente para la militancia travesti, así como para una enorme red afectiva de disidencias sexogenéricas y sexuales. 


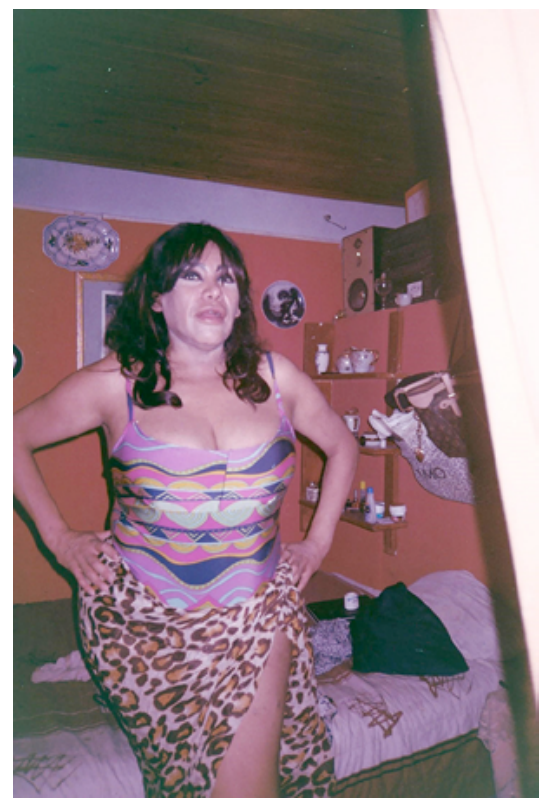

Imagen 1. Sin título. Fotografía de Lariza Hatrick. Shirley Bombón en la casa de los putos, quienes la alojaron para que cumpla prisión domiciliaria debido a una mega-causa narco-travesti.

sugerir la evanescencia de una alteridad que escapa, incluso, a las identidades que se delimitan dentro de los términos taxonómicos normativos convencionales pertenecientes al ámbito de la representación.

Así, la fotografía de Hatrick no puede ser adjetivada con el término queer. Utilizar la etiqueta queer para connotar la especificidad de un tipo de registro fotográfico contradice el sentido de esta perspectiva originalmente preocupada por socavar cualquier definición y significado fijos (Butler, El género 57). Justamente, la potencia cuir reside en cuestionar y retorcer el uso convencional de términos, textos y estéticas. Los registros fotográficos de Hatrick configuran un archivo que destrona la idea de fotografía vinculada con representaciones y conceptos hegemónicos de verdad y precisión. No sólo no se ajustan y cuestionan el ideal de excelencia artística, sino que, por su carácter bizarro, son propicios para deconstruir tales conceptos, y desestabilizan los sentidos convencionales que recubren las identidades legítimas, la historia oficial y la memoria entendida como registro y preservación de representaciones y materiales inteligidos e inteligibles de acuerdo con la matriz heterosexual.

El estilo fotográfico de Hatrick se aleja de nociones tales como excelencia, verdad y perfección. Sus fotografías no cumplen con los requerimientos técnicos de aquello que normativamente se valora como 'buena fotografía'. Pero allí reside la potencia estético-política que nos interesa. Lejos de preocuparse por el enfoque correcto, la buena exposición, sus fotografías no son técnicamente limpias ni equili- 


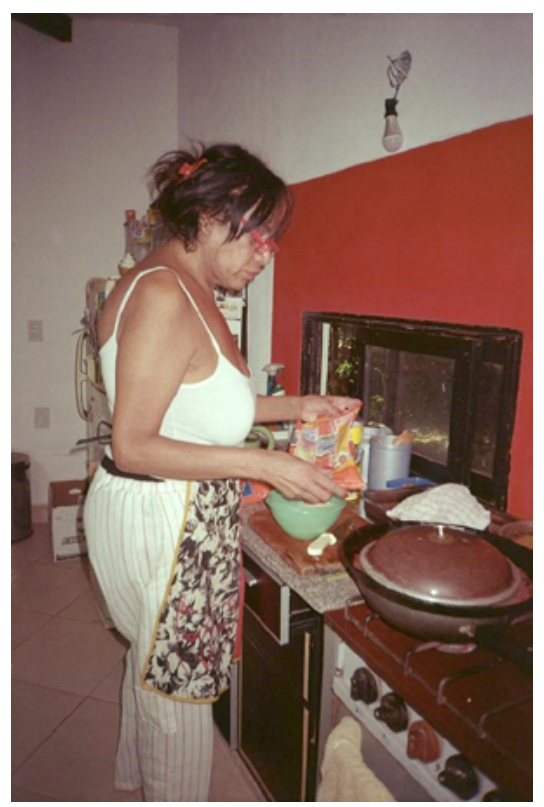

Imagen 2. Sin título. Fotografía de Lariza Hatrick. Shirley Bombón cocinando arroz con mucho ajo (comida de su país natal, Perú), en la casa de Lariza Hatrick.

Allí vivió hasta que comenzó a sufrir complicaciones de salud.

bradas. Sin embargo esta (des)composición fotográfica cumple con invocar un telón de fondo, no reductible a ninguno de los elementos que integran las imágenes, que podemos caracterizar como estética del fracaso. Sus imágenes perforan la mirada con una dimensión ontológica del fracaso imposible de ser redimida mediante estrategias discursivas. Aquello que impacta en su propuesta fotográfica no es reductible a una estrategia de representación visual clara y distinta ${ }^{7}$. Se trata de un registro experiencial capaz de extenderse más allá del contexto de sus fotografías.

Hatrick aporta condiciones de posibilidad no discursivas para experimentar varios tipos de fallas y fracasos políticamente productivos. Su estética del fracaso (muchas de sus fotos son granuladas, de baja resolución, o revelan fallas en el funcionamiento mecánico de su cámara) nos enfrenta con la eliminación de toda fantasía de control y dominio absoluto. El fracaso como experiencia y como estética

7 Intentamos abordar la potencia política y estética que emerge a partir de una negatividad vinculada con una alteridad radical que, como tal, no es reductible a ninguna estrategia de representación visual de la artista. Se trata de una afectación experiencial que nos aproxima a otros modos de vida abyectos (contextualmente situados) sin la mediación de los juegos de la representación, la reivindicación y el reconocimiento propio de la lógica de las identidades. 
nos conduce a nuestra estructura fallida. Sus imágenes hacen circular, recopilan, activan y potencian experiencias emergentes y amorfas sobre condiciones sociales de abyección que las estrategias que cabalgan sobre la positividad de los términos del lenguaje no pueden expugnar.

La estética del fracaso y los afectos asociados a ella nos invitan a alejarnos de imponer la grilla identitaria con la que contamos. Nos invitan a captar las vibraciones y los gestos de una sensibilidad ampliamente distribuida para comprender el fracaso que subyace a los gestos corporales. La pérdida de la fantasía de la 'buena vida' es una posibilidad para enfrentarnos con la negatividad que nace de la estructura fallida del sujeto y que se desnuda cada vez que abrazamos el carácter antisocial de aquello que no persigue los fines normativamente idealizados y valorados. Hatrick nos pide que registremos el fracaso de manera diferente. Lejos de aceptarlo, las fotografías de Hatrick nos invitan a agitarnos con él, a conducir nuestros cuerpos de manera improductiva en relación con los marcos de inteligibilidad que organizan nuestra mirada.

Jack Halberstam argumenta a favor de perseguir el fracaso como táctica para producir un cortocircuito y deshacer los puntos de referencia heteronormativos del éxito en la cultura occidental (El arte 34). El fracaso se acompaña de una serie de afectos negativos como la decepción, la desilusión y la desesperación, pero también brinda la oportunidad de usar estos afectos negativos para hacer agujeros en la positividad tóxica de las taxonomías discursivas que reciclan la frontera entre lo legítimo y lo ilegítimo. La fotografía de Hatrick se propone modificar la carga afectiva en torno al fracaso y perturba la trayectoria internalizada de la vergüenza. Agitarse con el fracaso interrumpe espasmódicamente la quietud de las identidades cisheteronormadas.

Al intentar caracterizar su producción fotográfica nos enfrentamos con el esfuerzo por retratar el trayecto de vidas singulares que transcurren por fuera de los marcos normativos de reconocimiento y, al mismo tiempo, propone una recuperación de la pura presencia abyecta evitando sentidos hegemónicos. Su fotografía, por un lado, socava las nociones de identidad fija y estable y, por otro, desarticula la posición de observación que generalmente afirma el dominio sobre lo otro devenido objeto pasivo de patologización, inferiorización, exclusión y forclusión simbólica. En algún sentido las fotografías de Hatrick desestabilizan las posiciones de sujeto-objeto, cuestionan las oposiciones binarias y desafían las categorías esencializadas en significados fijos - aun cuando estos refieren a identidades normativamente fijadas como sitios desposeídos a ser redimidos mediante políticas de reconocimiento-.

Si cobrar existencia en el orden simbólico hegemónico presupone la articulación bajo los términos de las representaciones hegemónicas, masculinistas y cisheteronormadas, Hatrick nos enfrenta con las existencias en su alteridad radical como una vía de acceso, no lingüístico, a presencias abyectas que hieren la pretensión de formas únicas de existir simbólicamente. Así, nuestra fotógrafa desafía radicalmente las relaciones de poder que subyacen a los modos en que denominamos lo Otro. Abre un espacio, en sus propios términos, para un tipo de registro fotográfico que cae por fuera de lo esperable. 
Hatrick no se contenta con habitar una parcela del terreno simbólico hegemónico - ni siquiera aquellas catalogadas como queer-. Tampoco se conforma con las migajas de reconocimiento que reciben las identidades carentes de legitimidad. Nuestra fotógrafa entiende que aquellas prácticas que hacen de la otredad una versión defectuosa de las identidades normativas se vinculan con el modo en que se distribuye el reconocimiento mediante la inteligibilidad articulada en la economía de la representación. Por ello, su registro fotográfico reconstruye historias abyectas desde la perspectiva de su propio mundo marginado. Su propuesta fotográfica constituye un acto de resistencia no sólo contra la ficción de una identidad coherente y estable, sino también contra un orden que sólo confiere existencia simbólica cuando logra reducir la alteridad radical en otredad hegemónica. La fotografía de Hatrick no busca convertirse en un concepto coherente y estable de resistencia, y por este motivo el valor último de su propuesta reside en el registro de historias olvidadas, historias que cuentan en sus propios términos, puesto que, finalmente, no encuentran sitio en la economía de la representación cisheteronormada.

Sin dudas, la operación política que Hatrick pone en marcha requiere de una crítica radical a conceptos como sexo, género, identidad, cuerpo y representación. A la fotógrafa no le interesa que su registro en imágenes se integre en la cultura contemporánea. Su mirada cuir se encuentra cargada de un exceso que late sin poder articularse por completo en la representación. Esto la vuelve capaz de recortar en cada foto no sólo el retrato de una persona singular, cuya identidad escapa a la cisheteronorma, sino una estética abyecta que señala un quiebre con las reglas estéticas frecuentemente valoradas. Por ello, justamente, su registro fotográfico es directo y al instante, y no se interesa en absoluto por la perfección técnica. Esta estética es consonante con el modo en que ella denomina a quienes retrata: monstruos. Tal denominación toma distancia de los términos con que la matriz heterosexual denomina las otredades para delimitarlas, producirlas y controlarlas en un proceso constante. Las fotografías de Hatrick plasman el comportamiento enormemente errático de las personas que cruzan los límites de lo legible. Su punto de mira abre otros modos de circulación y de existencia, y expone formas de presencias que, sin mediación identitaria, emergen más allá de la violencia epistémica que imponen los marcos interpretativos con los que contamos. Estas existencias que irrumpen mediante estéticas grotescas e hiperbólicas configuran, en la fotografía de Hatrick, una presencia perturbadora, pues exponen de forma inmediata aquello que Butler denomina la "condición de espectro amenazador" (Butler, Cuerpos 20). Butler ha advertido el modo en que opera "la producción de una esfera excluida que llega a delimitar y a atormentar el campo de la vida inteligible» (93) donde «la fuerza de la prohibición produce el espectro de un retorno aterrador» (93). Para la autora, estos espectros abyectos irrumpen en las posiciones del sujeto, por este motivo la producción cultural de memoria bien puede pensarse como operación subsidiaria a los continuos intentos de «destruir ese espectro para impedir el tipo de asociación que podría desestabilizar las fronteras territoriales» (265) de la cisheteronorma. Butler afirma que este espectro amenazador es «una parte interna del sistema y, por lo tanto, se presentará como el espectro que promete su desestabilización» (103). Esta existencia espectral está dentro del campo de lo representable. El modo en 


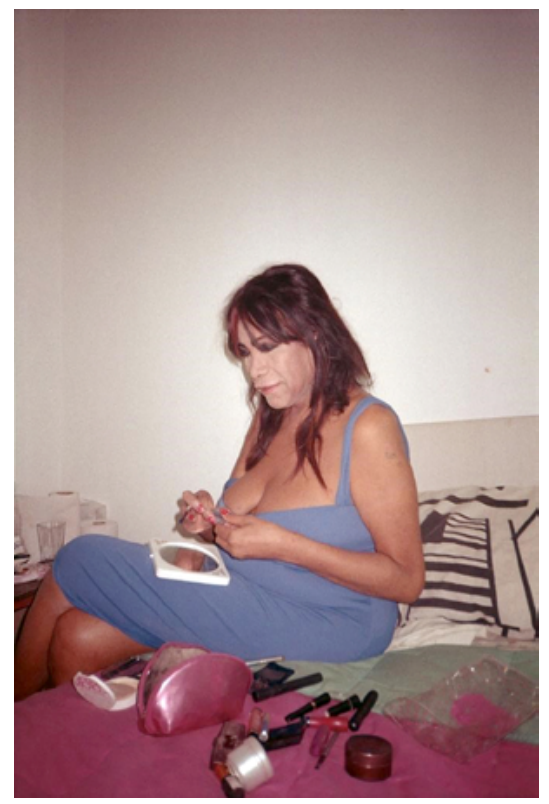

Imagen 3. Sin título. Fotografía de Lariza Hatrick. Shirley Bombón con sus enormes tetas y su maquillaje.

que elegimos interpretar la propuesta estética de Hatrick devela una operación que recupera aquella negatividad que hiere la economía misma de la representación. Para Butler este "espectro que evidentemente se produce, circunscribe y combate culturalmente» (133) «es el espectro del reconocimiento de que ya estuvo siempre perdido, la derrota de la fantasía» (154). Para Hatrick tal espectro descompleta cualquier reclamo de hacer justicia que se conduzca por la vía de la representación. Butler resuena en esta línea al mencionar que «el espectro restrictivo [...] constituye los límites demarcadores del intercambio simbólico» (157), asignándole el estatuto de «exterior amenazante» (157).

Sea como fuere, sus fotografías evocan la sensación de las instantáneas que retratan vínculos de mucha intimidad. Incluso escenifican dramas como el tránsito hacia la muerte provocada por el sida -uno de los aspectos que atraviesan las identidades y corporalidades de estos colectivos simbólicamente forcluidos-. En efecto, su archivo fotográfico personal cuenta con el registro de la muerte de algunas de sus amigas travestis. De este modo, la fotógrafa instala el sufrimiento como estética de vida que paga el precio por asumir sus propios términos.

La fotografía de Hatrick abre un espacio para la manipulación y autoinvención que escapa a las reglas de la representación moderna sobre las que cabalgan las identidades; por ello el registro de sus imágenes contradice la retórica y ficción de autenticidad del retrato fotográfico. Ella expone que detrás de la representación 
no hay referentes estables a partir de los cuales reclamar autenticidad, e insiste en borrar los límites entre la fotografía documental y la ficcional. Colapsar esta distinción le permite participar en primera persona mediante sus registros. Sin las marcas del registro, afirma, no hay memoria. Pero luego, tal registro no puede quedar anudado a ningún marco que fije de forma absoluta criterios de fidelidad. El registro es un hecho político, y se encuentra poblado de aspectos ficcionales. Por debajo de estos deslices móviles del sentido, la autora prioriza el puro registro insistente y perturbador de aquellas presencias que la memoria no tolera y, por ende, rechaza. ¿Existe algo más político que el rechazo mismo de las marcas que subyacen a las ficciones identitarias?

\section{PRIMEROS ELEMENTOS PARA UNA CONCEPCIÓN DE ALTERIDAD RADICAL}

Es sabido que la teoría queer ha tomado seriamente la tarea de esbozar una crítica feroz hacia los discursos cisheteronormados que involucran, entre otros aspectos, los vínculos sexualidad/cuerpo. Tal es el caso de Butler, quien no sólo ataca de forma asertiva la distinción sexo/género, sino que también devela los mecanismos a partir de los cuales se imponen identidades de género discretas y coherentes. Asimismo, ha colocado al cuerpo bajo examen crítico. A partir del prisma foucaultiano, Butler se dedicó a trazar una fuerte crítica a la clasificación en dos tipos de cuerpos con características natural y fácticamente diferentes. En este camino crítico, la autora se interroga respecto a la estabilidad de las categorías de género cuando advertimos la ausencia de un fundamento reificado, trascendente y necesario (Butler, Contingent 7).

La teoría queer, especialmente las versiones que se alimentan del pensamiento de Butler, se muestra en contra de cualquier compromiso metafísico implícito incuestionado e incuestionable. Desde aquí, alienta a concebir los fundamentos contingentes del orden social y subjetivo en términos discursivos. Aún más, afirma la resignificación de tales términos como estrategia política capaz de disputar los términos impuestos por los marcos normativos. Así, propone una forma de desnaturalizar y resignificar las categorías corporales a través de un conjunto de representaciones paródicas, lo que conllevaría una reflexión crítica sobre la ontología del género como una (de)construcción paródica, y quizá profundizaría en las posibilidades móviles de la espinosa diferenciación entre 'parecer' y 'ser', una radicalización de la dimensión de 'comedia' de la ontología sexual (Butler, El género 121).

Estas consideraciones subyacen a su noción de performativo, entendida como una potente herramienta teórico-política, pues permite impugnar los códigos dados de diferencia sexual. En este contexto Butler argumenta en contra de la fijeza de las identidades -en términos de profundidad interior y sustancial- y contra la naturalización de los cuerpos -en términos de superficie fáctica prediscursiva-. La preocupación por quitar del sexo cualquier fundamento esencial y natural se anuda con su comprensión del cuerpo en términos de una construcción discursiva. Así, la materialidad misma parece diluirse en el carácter significante atribuido al sexo: 
lo que constituye el carácter fijo del cuerpo, sus contornos, sus movimientos, será plenamente material, pero la materialidad deberá reconcebirse como el efecto del poder, como el efecto más productivo del poder. Y no habrá modo de interpretar el 'género' como una construcción cultural que se impone sobre la superficie de la materia, entendida o bien como 'el cuerpo' o bien como su sexo dado. Antes bien, una vez que se entiende el 'sexo' mismo en su normatividad, la materialidad del cuerpo ya no puede concebirse independientemente de la materialidad de esa norma reguladora (Butler, Cuerpos 18-19).

En la insistente afirmación butleriana del carácter social e históricamente construido de la materialidad de los cuerpos - de la materialidad del sexo- anida su temor construccionista por tropezar con el esencialismo y el ahistoricismo. Desde la propuesta de Butler los procesos de construcción y producción de memoria no pueden ser pensados al margen de los marcos normativos de inteligibilidad que ella misma ataca. La memoria suele ser delimitada como una representación activa del pasado y «se articula en un proceso discursivo complejo en el cual se acoplan recuerdos, olvidos, silencios y represiones, tanto conscientes como inconscientes» (Cutuli e Insausti 24). ¿Pero cómo pensar la potencia subversiva de aquello que, aunque forcluido del discurso, es resistente a la norma en su pura presencia y alteridad?

En las tramas de esta perspectiva queer-que ha hegemonizado el debate académico en el medio local- cobra sentido la relevancia de hace lugar a la irrupción crítica de estéticas locales disidentes. Tal es el caso de Hatrick, quien nos ofrece registros de existencias abyectas que no transcurran por los carriles discursivos de la matriz heterosexual. Butler misma ha señalado que aquellos sujetos que caen por fuera de los criterios de inteligibilidad son borrados simbólicamente. Ante esta operación de forclusión, Hatrick se empeña en recuperar las marcas concretas en su alteridad radical -respecto de lo que el orden simbólico representa como legítimo e ilegítimo-, y escoge el registro fotográfico como forma de atravesar el muro del construccionismo social que forcluye el territorio de la negatividad sobre la que cabalgan formas de alteridad radical irreductibles a los términos normativos. Su activismo se empeña por hacer lugar a presencias abyectas que el registro escénico captura de forma privilegiada. La fotografía de Hatrick nos permite imaginar una reformulación del modo en que se trazan los límites territoriales que divide la memoria de lo legítimo, el olvido de lo ilegítimo y la forclusión, y el destierro, de lo abyecto.

Interesa sugerir que las estrategias políticas ancladas en el discurso arrastran consigo los límites que restringen la posibilidad de una transformación radical del campo simbólico. Eduardo Viveiros de Castro plantea la continuidad ontológica entre estas ausencias ininteligibles, pues todas ellas comparten un mismo gesto de exclusión radical (Viveiros de Castro 19). Más allá de las grillas identitarias, este «trazado de un plano de inmanencia común» en la alteridad (Viveiros de Castro 239) se muestra resonante con los planteos de Lee Edelman en torno a «la queeridad vinculada de forma irreductible a lo aberrante y atípico, a aquello que escuece la normalización» (Edelman 24). Así, la ajenidad radical emerge como una negatividad queer que no persigue la positividad de ningún valor social (Halberstam 140).

Estas consideraciones sugieren que el pensamiento queer se socava a sí mismo cuando no enfrenta un examen profundo de los límites con los que el len- 
guaje mismo tropieza. La pura presencia del registro fotográfico de Hatrick señala los límites del monismo lingüístico de las versiones más difundidas de la teoría queer. La pseudopotencia deconstructiva de la resignificación lingüística colapsa y se disuelve en los mismos términos discursivos y normativos que propone. Así, la pretendida potencia de la noción de Diversidad enmascara la problemática lógica de La Diferencia -a partir de la cual se distribuye el reconocimiento simbólico-. En este contexto, a partir de la mirada cuir de Hatrick proponemos aproximarnos a la noción de alteridad radical. Esto nos permite tomar distancia crítica respecto de los límites de la lógica de La Diferencia que subyace a la territorialización de lo Uno y lo Otro. Si la diferencia ha sido delimitada históricamente en términos de represión o de Otro excluido, Allison Weir argumenta la necesidad de «distanciarnos de las formas particulares en que hemos sido atrapados en represiones de la diferencia, con una lógica de sacrificio y exclusión» (Weir 3), donde la imposición discursiva de Lo Mismo reprime la posibilidad de una diferencia que valga en sus propios términos. Después de todo, Lo Mismo es una proyección de la esfera de la representación, un borramiento eficaz de cualquier forma de diferencia radical respecto a lo simbólico (Irigaray 19).

\section{EL REGISTRO DE LA PRESENTACIÓN DEL CUERPO, MÁS ALLÁ DEL LENGUAJE}

El posestructuralismo, vertebral para la teoría queer, ha demonizado, bajo el mote de esencialismo, cualquier intento de deslindar un resto corporal no reductible a la raigambre discursiva de los marcos identitarios. Desde este punto de mira, aquellos aspectos no subsumibles al lenguaje son absorbidos en un allá afuera que frecuentemente cobra la forma discursiva de naturalización. Aquí optamos por reconocer la presentación perturbadora y abyecta de una alteridad radical, jamás susceptible de ser apresada completamente en una representación. De lo contrario, las estrategias de legitimación del campo simbólico mostrarían un poder omnímodo y no sería factible abordar seriamente la posibilidad de su transformación radical. En este sentido, la experiencia y el registro escénico y estético que ofrecemos nos permite, por un lado, sospechar y apelar a una dimensión no reductible a la clásica y estéril oposición entre esencialismo (biológico) y construccionismo (social). Por otro, nos resguarda de cualquier desliz hacia los términos taxonómicos que la cisheteronorma codifica para etiquetar la otredad -o el reflejo deformado del sujeto normal, modélico y neutro-.

Es innegable que el lenguaje territorializa y consolida las identidades, también que los cuerpos emergen bajo identidades sexuales y genéricas que son efecto de marcos binarios de inteligibilidad -en la misma línea, Thomar Laqueur señala que «la epistemología no produce dos sexos opuestos por sí misma; eso sólo lo pueden hacer ciertas circunstancias políticas» (Laqueur 32)-. Aun así, Hatrick parece no someterse a la exhortación del alcance ilimitado del lenguaje y de la construcción discursiva. Su fotografía nos enfrenta con una experiencia estética capaz de sostener una recuperación no reductible a la apresurada irrupción normativa de una identidad claramente 


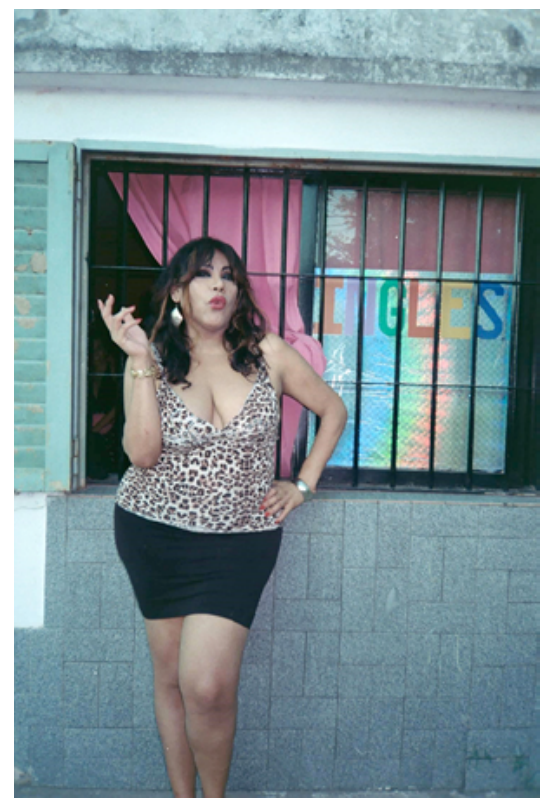

Imagen 4. Sin título. Fotografía de Lariza Hatrick. Shirley Bombón en la ventana de la casa de las maricas, donde se enseñaba inglés.

territorializada. Por el contrario, nos desafía a desentrampar el cuerpo de la lógica binaria que el lenguaje promueve y a evitar aquella «violencia epistémica manifiesta en la exotización y en la más brutal esencialización» (Figari 71). Hatrick no reduce su mirada a este enorme obstáculo epistemológico, más bien apuesta por la proliferación de otras cartografías corporales y existencias posibles. La fotógrafa se interroga ¿qué otros marcos epistemológicos nos guiarán en la reterritorialización de los cuerpos?

$\mathrm{Al}$ respecto, Tom Boellstorff señala la estrecha proximidad epistemológica que existe entre la teoría cuir y la antropología. Lejos de afirmar que debemos etnografiar la teoría queer, nos propone pensar que la antropología puede conectar con la principal fuerza impulsora de lo que aquí denominamos como cuir: la alteridad. Sin embargo, como señalamos, no se trata de aquella alteridad delimitada a partir de un conjunto de características diferentes a la norma social que se impone bajo el sello de una pretendida universalidad -noción de alteridad notoriamente problemática debido a que invoca fantasmas vinculados con los orígenes coloniales de la antropología-. En este sentido la alteridad cuir que aquí nos interesa se aleja de las complicidades epistemológicas que exotizan la diferencia y defienden el retorno acrítico a un espacio salvaje esencializante. Si nuestro orden simbólico, que organiza las diferencias en torno a un único marco normativo, "no puede concebir la copresencia sin incorporación» (Boellstorff 243), entonces nos interesa, junto a Hatrick, aquel resto de alteridad imposible de ser incorporada. La alteridad que la teoría cuir 


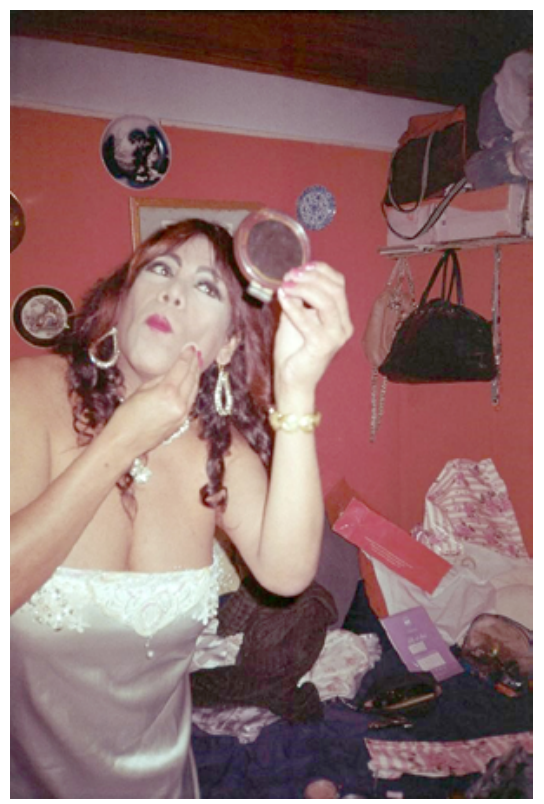

Imagen 5. Sin título. Fotografía de Lariza Hatrick. Shirley Bombón en el día de su casamiento.

En el año 2010 fue sancionada en Argentina la Ley de Matrimonio Igualitario.

proyecta no refiere a una colección de identidades ordenadas bajo la égida de un centro normativo que opera como patrón universal de medida. Más bien se trata de aquella alteridad que no logra organizarse bajo una identidad coherente y, desde los intersticios, desestabiliza radicalmente la realidad que se da por sentada. La alteridad, en términos cuir, refiere a la posibilidad permanente de ser otro, a punto tal de concebir una forma radical de lidiar con la diferencia.

Desde esta perspectiva, las identidades sexogenéricas y sexuales no normativas no deben identificarse, sin más, con la alteridad cuir, puesto que estas identidades continúan articuladas bajo los términos normativos de la matriz heterosexual. Más bien, la propuesta transcurre por desarticular radicalmente el deseo más allá del marco restrictivo de la sexualidad. Ya es ampliamente sabido que, de acuerdo con Michel Foucault, el dispositivo de la sexualidad configura un régimen moderno de saber/poder que produce la sexualidad como una orientación y un dominio psicosexual medicalizado capaz de alojar la verdad oculta sobre el ser del sujeto (Foucault 19). Desde aquí, muchos intelectuales han cuestionado la potencia subversiva de identidades sexuales no normativas, pues han señalado las profundas limitaciones de cualquier marco analítico que restrinja la potencia erótica a partir de la lógica de las identidades. Hatrick sabe que la pretendida fuerza crítica de la teoría queer no es inmune al perdurable control del dispositivo de la sexualidad sobre nuestros intentos de pensar el cuerpo y su economía deseante. 


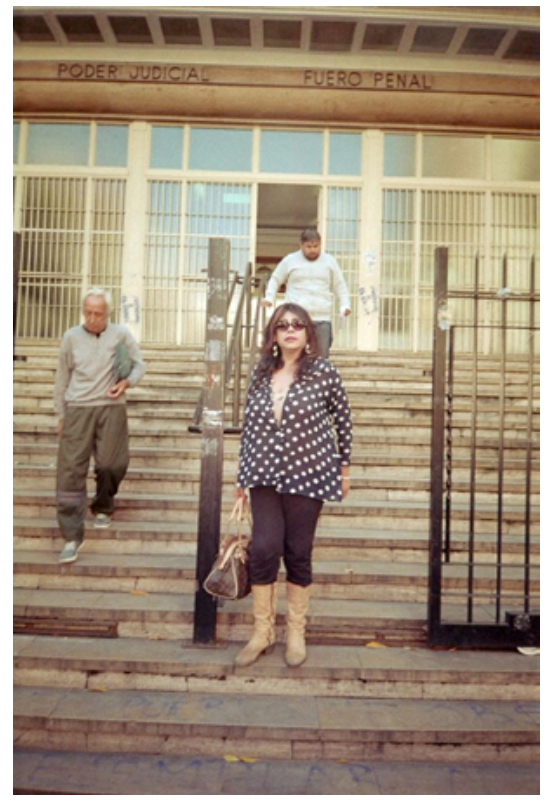

Imagen 6. Sin título. Fotografía de Lariza Hatrick. Shirley Bombón en la entrada del poder judicial de la ciudad de La Plata.

A pesar de que, indudablemente, la teoría queer es conceptualmente productiva, tiende a limitar la mayor parte de su propuesta con versiones de la diversidad que no alcanzan grados de radicalidad como para trasladar el pensamiento más allá de las categorías hegemónicas ya delineadas por el propio dispositivo que se pretende dinamitar. Es por ello que el pensamiento queer continúa prisionero de los términos establecidos y es por ello que la fotografía de Hatrick y su mirada cuir irrumpen como una alternativa situada capaz de contextualizar la potencia de formas particulares de existencia capaces de permitirnos pensar la forma en que la cisheteronorma tropieza consigo misma en su intento de absorberlo todo. Aun así, Judith Butler nos recuerda que

Si ciertas vidas no se califican como vidas o, desde el principio, no son concebibles como vidas dentro de ciertos marcos epistemológicos, tales vidas nunca se considerarán vividas ni perdidas en el sentido pleno de ambas palabras. [...] El 'ser' de la vida está constituido por unos medios selectivos, [...] debemos hacer más precisos los mecanismos específicos del poder a través de los cuales se produce la vida (Butler, Marcos 13-14).

En la fotografía de Hatrick no importa tanto la identidad con la que Shirley Bombón se identifica como el hecho de que ella alegoriza el tropiezo de la representación y los mecanismos específicos del poder a través de los cuales se produce la 
vida. Una alteridad abyecta donde anida la potencia radicalmente crítica de la teoría cuir. Si en la alteridad yace la expresión de un mundo posible, entonces el registro estético cuir es un operador epistemológico capaz de refigurar una recuperación de lo abyecto inasimilable a lo simbólico. Tal como señala Edelman, la cisheteronorma siempre nos cobra, y pagamos a nuestras expensas cualquier renegación de las marcas identitarias que el orden simbólico impone:

(aunque como sujetos simbólicos destinados a figurar la ruina de lo Simbólico estemos sujetos a la necesaria contradicción de intentar volver su inteligibilidad contra él mismo), podríamos de forma figurada dar [...] primacía a un no constante en respuesta a la ley de lo Simbólico, lo que evocaría el acto fundacional de esa ley, su negación auto-constituyente (Edelman 22).

Por su parte, y en esta dirección, Gilles Deleuze caracteriza a las identidades y la diferencia que el orden simbólico produce en términos de grilletes de la mediación representacional (Deleuze 92). A partir de esta noción, Guy Hocquenghem supo alojar el deseo en el territorio de la alteridad radical que seńalamos. Hocquenghem afirma que las identidades sexuales son meras segmentaciones arbitrarias del flujo ininterrumpido y polívoco del deseo, un plano inmanente donde transcurren las intensidades corporales que la gran maquinaria social requiere y, al mismo tiempo, reprime (Hocquenghem 22). En alusión al pensamiento lacaniano, Lee Edelman denomina Goce a esta dimensión deseante nunca reductible al orden social:

tomar la negatividad de lo Simbólico al pie de la letra de la ley, [...] escuchar la persistencia de algo interno a la razón que la razón rechaza, [...] volver la fuerza de la queeridad contra todos los sujetos, por muy queers que sean, puede permitirnos un acceso al goce que nos define y nos niega al mismo tiempo. Mejor aún: puede exponer la constancia, lo inevitable de tal acceso al goce en el orden social mismo (Edelman 22-23).

La alteridad radical que envuelve la negatividad cuir no se diluye en la positividad de los términos que pueblan el orden simbólico. Freud nos ha señalado el costado mortífero de la irracionalidad de las pulsiones que no reconocen fines sociales ni subjetivos (Freud 18). Incluso Paul Preciado ha recogido notoriamente el guante de este planteo psicoanalítico al plasmar su noción de potentia gaudendi: «se trata de la potencia (actual o virtual) de excitación (total) de un cuerpo. Esta potencia es una capacidad indeterminada [...] no reconoce diferencia heterosexualidad y homosexualidad» (Preciado 38). En este espectro teórico-político, Carlos Figari señala la relevancia de

ese exceso que nunca deja que lo simbólico cierre del todo y mantiene abierta la autocreación [...]. Paradoja de salir de nuestras identidades para hacer en otras, pero también para hacer mella en ellas. No es posible salir de un mundo de reflejos y/o relatos, mientras el mundo de lo simbólico exista [...]. La sutura de un sentido implica situación, identificación, aunque sea provisoria [...] pero no creamos y afirmemos que somos una comunidad, no sólo por respeto a quienes dejamos afuera sino en honor a quienes podríamos ser mañana (Figari 76). 


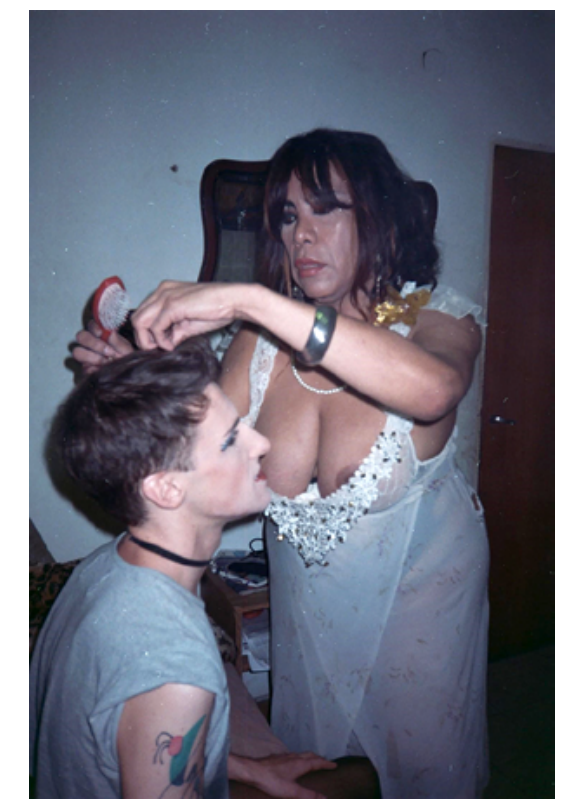

Imagen 7. Sin título. Fotografía de Lariza Hatrick. Shirley Bombón colaborando en el montaje de una de las maricas.

En suma, lo cuir resuena en la presencia de la alteridad inesperada que late en el fondo del alcance pretendidamente exhaustivo de toda identidad. Cuir deviene puro destierro corporal subsistente aun bajo la imposición de cartografías identitarias. Así, las fotografías de Hatrick figuran un sitio alegórico que señala una ola de potencialidad crítica imposible de ser completamente apresada o exorcizada por la positividad de los términos del lenguaje. De hecho, los mostris que pueblan sus fotografías no reconocen ni persiguen un fin social, tampoco regulación simbólica. Sus imágenes señalan la negatividad y lo socialmente inconducente, la espina clavada en la totalización de la eficacia de la norma.

Esta propuesta de enfocarnos en la fotografía de Hatrick como vía epistemológica de recuperación cuir de lo discursivamente irrecuperable es, también, un intento de reconectar la teoría queer con la crítica radical cuyo potencial es capaz de alterar nuestro pensamiento justo antes de ser sofocado bajo el peso de la anestesia del canon queer. El enfoque en la negatividad, en lo que radicalmente se opone y retorna en exceso perturbador, revela constantemente las inestabilidades internas de cualquier marco social, subjetivo, simbólico, normativo, teórico o identitario. La negatividad cuir prolifera indefectiblemente dentro de los marcos normativos, y distorsiona las ontologías homogéneas que se arrogan el poder de fundamentar un punto de vista queer. La negatividad cuir nos enfrenta con la posibilidad de un mundo radicalmente diferente, de corporalidades radicalmente 


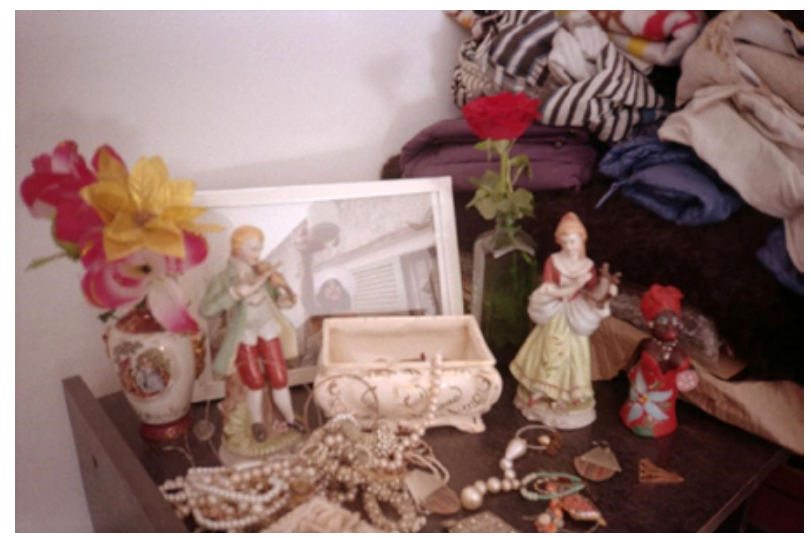

Imagen 8. Sin título. Fotografía de Lariza Hatrick. Objetos antiguos de Shirley Bombón adquiridos en su paso por diferentes países, incluidos varios europeos, especialmente Italia.

diferentes, y posibles debido a la potente actualización cuir de las múltiples virtualidades de lo inarticulable.

Desde esta mirada, Hatrick intenta trastornar, alterar, el mapeo hegemónico del cuerpo, ya sea heterosexual, homosexual, varón, mujer, travesti, trans - después de todo se trata de parcelas pertenecientes al mismo territorio simbólico-. Por tanto, nuestra fotógrafa asume el compromiso de rescatar radicalmente el fracaso ontológico que fractura al sujeto racional moderno, autoconstituido, voluntario y libre. La experiencia estética de la fotografía de Hatrick perturba las codificaciones hegemónicas al capturar de súbito la negatividad y al apelar a la intensidad, al exceso, al deseo mismo, a aquello ante lo cual el lenguaje fracasa rotundamente. Por este motivo su propuesta no se dirige hacia identidades no legítimas, sino más bien hacia la negatividad que cuestiona la distinción cisheteronormativa entre lo legítimo y lo ilegítimo. Así, las referencias identitarias ordenadas bajo las coordenadas significantes se desdibujan y dispersan.

\section{REFLEXIONES FINALES: DE LO POÉTICO A LO POLÍTICO}

Sin dudas, la formación de recuerdos colectivos es un proceso político y supone arreglos de poder donde los marcos cisheteronormativos se empeñan en encriptar la alteridad bajo categorías taxonómicas hegemónicas. En este contexto, las marcas simbólicas y materiales producidas por existencias abyectas configuran inscripciones forcluidas del campo simbólico. El despliegue de estas existencias abyectas (re)presenta peligrosas fuerzas para el mantenimiento de la norma social. La fotografía de Hatrick nos recuerda que si bien las representaciones pueden ser manipuladas por los arreglos de poder, las presentaciones en cambio pueden establecer la irrupción de aquello que no se ajusta a la cisheteronorma mediante la cual el 


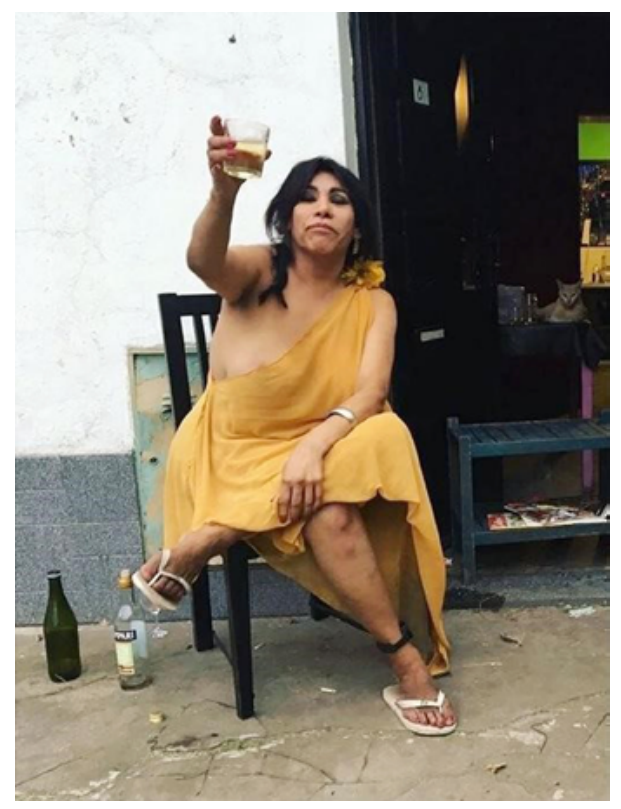

Imagen 9. Sin título. Fotografía de Lariza Hatrick. Fotografía publicada en el Instagram de Hatrick. Se acompaña del siguiente texto: «Nuestra amiga la Sra. Shirley está internada en terapia intensiva, muy comprometida en su capacidad respiratoria. Pasamos por un momento muy triste, nuestros sentimientos van desde angustia, hasta odio por un mundo cisheterosexual de mierda que es responsable, junto a las familias y al Estado. Somos su lacra, pero también queremos ser su pesadilla. Su estado es muy crítico. No se sabe si podrá salir de esa situación. ¿Por qué tenemos que pasar por estas cosas? ¿Por qué es esperable que nuestras amigas travas tengas estas vivencias? Castigan nuestra disidencia con la muerte. Tengo odio. Mucho. Invitamos a quienes se sientan sensibles ante este odio y tristeza a que se organicen para colaborar económicamente y emocionalmente en el proceso que nos espera. Fuerza travesti y amor disidente para la señora, baila Shirley!!».

orden simbólico y el orden normativo se reciclan a sí mismos. En suma, la fotografía de Hatrick rastrea marcas abyectas forcluidas. En ese sentido la interrupción o contestación de marcos colectivos de memoria - cisheteronormada- se vuelve políticamente potente.

Butler señala que todo «acto es en sí mismo una repetición, una sedimentación y un congelamiento del pasado que precisamente queda forcluido por su semejanza con el acto" (Butler, Cuerpos 29). Si la cisheteronorma sedimentada en cada acto corporal obtura la posibilidad reflexiva y crítica respecto al pasado y, por esto mismo, todo «acto es siempre una falla temporal de la memoria» (Butler, Cuerpos 29), entonces el registro fotográfico abyecto de Hatrick no sólo permite una desarticulación de aquellos actos 'normales' y normados, también abre espacios temporales mediante un registro que construye un pasado para aquellas existencias radicalmente otras que, en tanto abyectas, no encuentran sitio en la memoria ni en el olvido. 


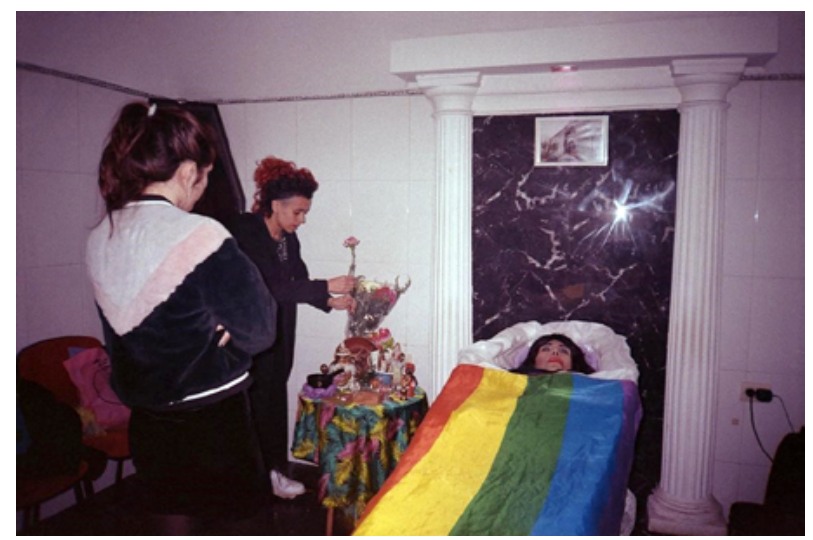

Imagen 10. Sin título. Fotografía de Lariza Hatrick. Velorio de Shirley Bombón.

En una de sus visitas a la Argentina, Butler se refirió a la memoria como un lugar en el que residen las emociones más conflictivas; por tal motivo, la memoria resulta creativa y devastadora. Desde su punto de vista, los archivos y la recuperación de existencias abyectas resulta de enorme importancia, pues la memoria del pasado se vincula con la posibilidad de proyectar el futuro. Aún más, la autora destaca la relevancia de reconocer la singularidad de nuestras vidas, pero también de ver las formas en que nuestras vidas se entraman con otras. Entonces, cualquier registro de recuperación de presencias se vuelve simbólica y materialmente vital para aquellas existencias que han sido borradas simbólicamente. Por su parte, Hatrick tuerce la memoria cultural a partir de su registro fotográfico. Su fotografía deviene artefacto político mediante el cual nos enfrenta con la alteridad radical que necesariamente excluimos como condición de posibilidad para acceder a un pasado hegemónico.

Por otra parte, Butler propone pensar en la fantasía de una fantasía para hacer referencia a la ausencia de un original que brinde terreno sólido para el despliegue de las identidades. También sostiene la importancia de que «la identificación deba transformarse en una realización viable» (Butler, El género 136). No fue el caso de Shirley Bombón:

La Shirley Bombón se fue. La Shirley murió. La mataron. La asesinó la cisheterosexualidad normativa. La asesinó un Estado abandónico. Al menos llegué a compartir [...] su increíble vida, sus historias, sus viajes, su simpatía, su enorme corazón tan grande como sus tetas de matrona. Me forcé en ir al velorio [...]. Llego y están todas las tortas, las maricas, las travestis, los pibes trans. 'Esta hermosa maquillada'. [...] En la habitación ella espléndida, lista para una gala. Las tortas la maquillaron. [...] la bandera del orgullo con muchas flores arriba del cajón [...]. Todavía estoy escuchando sus viajes por el mundo y viendo sus fotos cuando era una niña marica en su Perú natal (Rojas 83-84). 

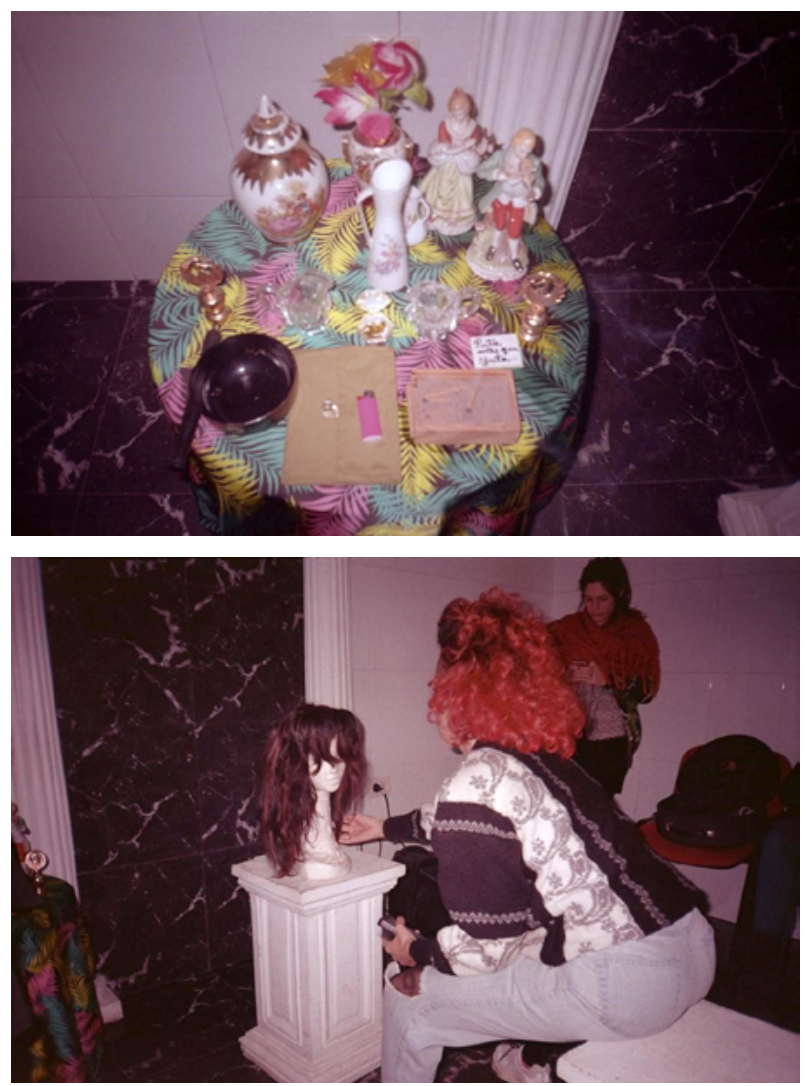

Imagenes 11 y 12. Sin título. Fotografías de Lariza Hatrick Fotos. Objetos (entre ellos la peluca) de Shirley Bombón en su velorio.

Las fotografías de Hatrick registraron la muerte de Shirley el 14 de agosto de 2018. En esta oportunidad, nos muestra con crudeza que el mundo es muy pequeño y sin aire, y no aloja el deseo, la fantasía, las contradicciones, la inestabilidad de las identificaciones y el dolor, ámbitos ante los cuales las identidades fallan. La crudeza del registro fotográfico nos indica que la muerte de Shirley Bombón es tanto un momento poético como político. Y así, nuestra mirada cuir debe admitir la vida material de los cuerpos y su continuidad con los objetos que configuran su mundo, y a través de los cuales su existencia, de algún modo, se prolonga.

Butler dedicó amplio espacio de su producción reciente a la desposesión, y a la vulnerabilidad a la que estamos sometidos por nuestra existencia corpórea. Adriana Cavarero afirma que todo cuerpo es vulnerable puesto que siempre está abierto a la herida del otro (Cavarero 43). Este rasgo ontológico se ve redoblado cuando las normas sociales ejercen violencia recrudeciendo tal carácter vulnerable. En términos de Butler, la precariedad se torna precaridad, una 


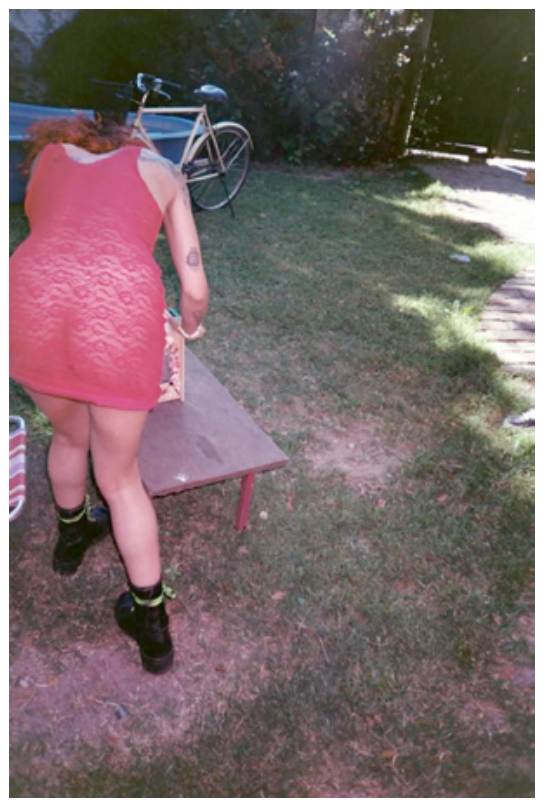

Imagen 13. Sin título. Fotografía de Lariza Hatrick. Amiga de Shirley Bombón abriendo las cenizas luego de su cremación.

nueva ontología corporal que implique repensar la precariedad, la vulnerabilidad, la dañabilidad, la interdependencia, la exposición, la persistencia corporal [...]. El 'ser' del cuerpo al que se refiere esta ontología es un ser que siempre esta entregado a otros: a normas, a organizaciones sociales y políticas que se han desarrollado históricamente con el fin de maximizar la precariedad para unos y de minimizarla para otros (Butler, Marcos 15).

Hatrick no desconoce que la falta de inteligibilidad acabó con la existencia material de Shirley Bombón. Claro está, no defendemos el abandono absoluto de la potencia política de las identidades, pero sí sostenemos lo que la propia Butler observa:

Mi preocupación es que, si aceptamos las normas dominantes que gobiernan el reconocimiento, terminemos abandonando a lxs que están en los márgenes [...] o creando una nueva serie de márgenes [...]. Estoy a favor de 'volverse inteligible' y, al mismo tiempo, soy consciente de que debemos ser críticxs de los modos dominantes de inteligibilidad (Cano y Fernández Cordero 26).

Lo cuir, tal como lo hemos planteado, debe apelar a las identidades como complemento de las políticas que se proponen ampliar el reconocimiento. Pero la negatividad cuir nos advierte contra la naturalización/despolitización de la identidad recubierta de un exterior de cambio y transformación. Las reflexiones cuir en torno 


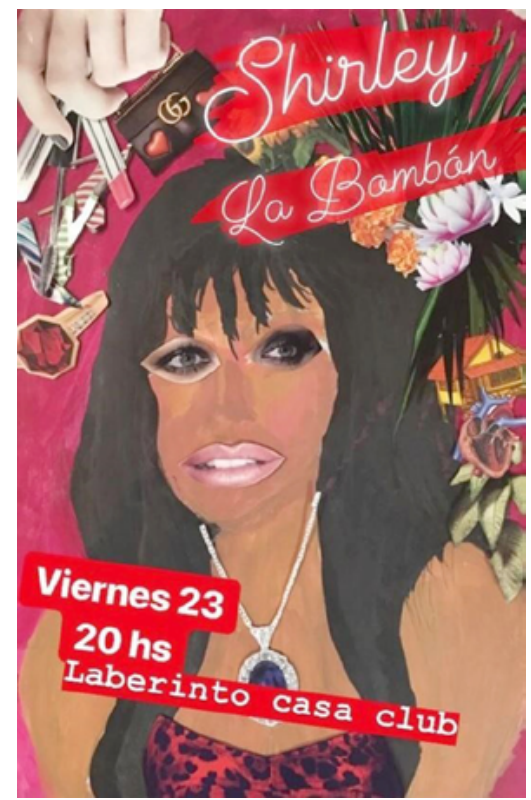

Imagen 14. Sin título. Afiche de la exposición de fotos y objetos de Shirley Bombón en Laberinto Casa Club, meses después de su muerte en 2018. El evento se promocionó por https://www.facebook.com/laberintocasaclub con el siguiente texto: «Shirley La Bombón. Exposición e Invocación. El 14 de agosto la Shirley se fue y nos dejó con mil preguntas para hacerle y cosas que queríamos compartir con ella. Desde ese día todo el tiempo la extrańamos y todo el tiempo nos hace falta. Así, no podemos. Por lo tanto, decretamos que el tiempo y la división vida-muerte es heterosexual y occidental y no nos concierne: este viernes la invocamos. La Shirley está en sus porcelanas barroquísimas, en su altar budista, en el arroz con banda de ajo, en sus cuadros y en sus dibujos, en Italia, en Perú, en la Zona Roja, en la Cumbre, en los audios contando anécdotas y hablando en italiano, en todos nuestros esfuerzos por retratarla y atesorar un poquitito de todo lo hermosa que era. Esta noche nos encontramos en una ronda alrededor de la ouija, hacemos un largo y profundo ta ta takataka ta y la traemos de vuelta para celebrarla».

a la propuesta fotográfica de Hatrick nos alertan sobre lo queer devenido camuflaje perfecto de identidades fijas y estables.

Como se ha señalado, la alteración política de la mirada propuesta por Hatrick enfatiza que tanto la otredad como la identidad coexisten en pugna. Los retratos de Shirley Bombón hacen presente la experiencia de insuficiencia y desintegración que nos habita mediante aquella negatividad que no reconoce territorio identitario - allí donde la alteridad trastorna nuestra mismidad arrojándonos fuera de nosotros mismos y borrando el abismo que nos separa de la otredad-. Nuevamente, esto no supone negar la relevancia de aquellas claves políticas que permiten explicar la degradación de ciertas identidades no legítimas que pagan el precio de la exclusión. 


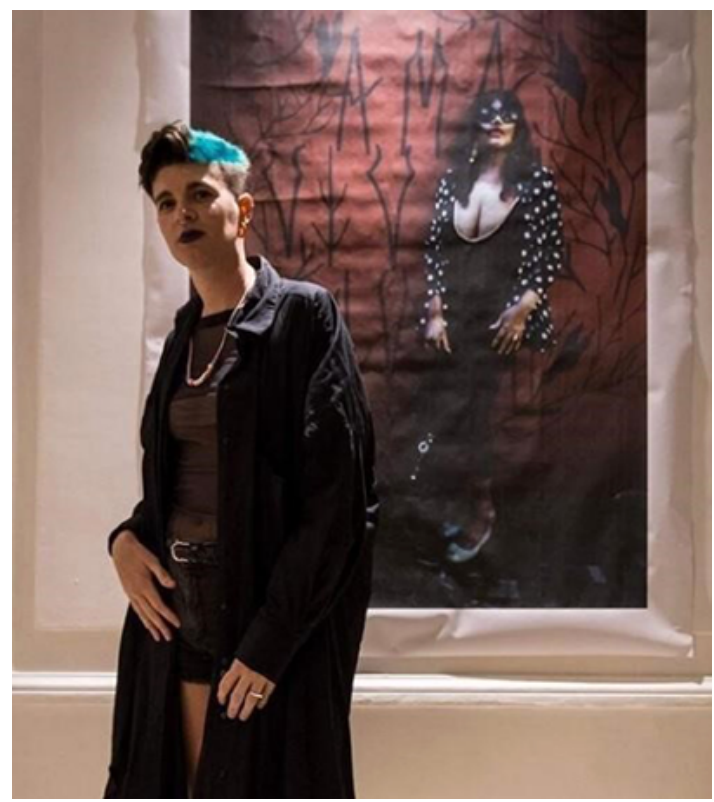

Imagen 15. Foto sin título. Lariza Hatrick junto a uno de sus retratos de Shirley Bombón.

Extraída de Instagram https://www.instagram.com/laberintocasaclub.

Hatrick nos muestra que el desvío, la interrupción, el fracaso, la incoherencia, la desposesión y la muerte forman parte del modo en que ontológicamente transcurrimos y nos deshacemos. En este sentido su trabajo fotográfico es cuir en tanto propone mirarnos desde 'donde no estamos', porque en ese 'allí' se juega más claramente nuestra mismidad, es decir, las fuerzas que perturban las identificaciones que deambulan por zonas extranjeras con respecto a nuestras identidades. Nos insta a recuperar la memoria de nuestra desposesión y a enfrentarnos con la alteridad radical que, indefectiblemente, nos enfrenta con el fracaso. La existencia ininteligible de Shirley Bombón continúa inundándonos con sus marcas, y nuestra fotógrafa ha ido al rescate de esta potencia cuir.

Finalmente, resta destacar que Butler apela a la identificación melancólica freudiana para señalar que «la pérdida del otro a quien uno desea y ama se vence mediante un acto específico de identificación que intenta incorporarlo a la estructura misma del yo» (Butler, El género 138). Así sabemos que Shirley Bombón, al igual que todas las travas, tortas y maricas muertas, continúan con la fiesta de su existencia politizando nuestras vidas. Están desde su alteridad, en nuestra mismidad, contaminando nuestras identidades. Este trabajo le pertenece. 


\section{REFERENCIAS}

Boellstorff, Tom. «When Marriage Falls: Queer Coincidences in Straight Time». GLQ: A Journal of Lesbian and Gay Studies, 13 (2007), pp. 227-248.

Butler, Judith. «Contingent Foundations: Feminism and the Question of 'Postmodernism'», en Butler, Judith \& Scott, Joan W. (eds.), Feminists Theorize the Political, Cambridge University Press, 1994, pp. 153-170.

Butler, Judith. «Against Proper Objects», differences: A Journal of Feminist Cultural Studies, 6:2-3 (1994), pp. 1-26.

Butler, Judith. Cuerpos que importan. Sobre los limites materiales y discursivos del "sexo». Buenos Aires: Paidós, 2008.

Butler, Judith. El género en disputa. El feminismo y la subversión de la identidad. Barcelona: Paidós, 2007.

Butler, Judith. Marcos de guerra. Las vidas lloradas. Buenos Aires: Paidós, 2009.

Cano, Virginia y Fernández Cordero, Laura. Vidas en lucha. Conversaciones. Buenos Aires: katz, 2019.

Cavarero, Adriana. Horrorismo: Nombrando la violencia contemporánea. Barcelona: Anthropos, 2009.

Cutuli, María Soledad e Insausti, Santiago Joaquín. «Cabarets, corsos y teatros revista: espacios de transgresión y celebración en la memoria marica», en Peralta, Jorge Luis y Mérida Jiménez, Rafael (eds.), Memorias, identidades y experiencias trans. (In)visibilizaciones entre Argentina y España, Buenos Aires: Biblos, 2015, pp. 19-40.

De Lauretis, Teresa. Freud's Drive: Psychoanalysis, Literature and Film. London: Palgrave Macmillan, 2008.

Deleuze, Gilles. Diferencia y repetición. Buenos Aires: Amorrortu, 2002.

Edelman, Lee. No al futuro: la teoría queer y la pulsión de muerte. Madrid: Egales, 2014.

Foucault, Michel. La voluntad de saber. Historia de la sexualidad, vol. 1. México: Siglo XXI, 2008.

Figari, Carlos. «Fagocitando lo queer en el cono sur», en Falconi Trávez, Diedo, Castellanos, Santiago y Viteri, María Amelia (eds.), Resentir lo queer en America Latina: diálogos desdelcon el sur, Madrid: Egales, 2014, pp. 63-80.

Freud, Sigmund. «Más allá del principio de placer», en Obras Completas, tomo XviII, Buenos Aires: Amorrortu, 1979, pp. 1-62.

Halberstam, Jack. «The anti-social turn in queer studies», Graduate Journal of Social Science, 5:2 (2008), pp. 140-156.

Halberstam, Jack. El arte queer del fracaso. Madrid: Egales, 2018.

Irigaray, Luce. Espéculo de la otra mujer. Madrid: Akal, 2007.

Kristeva, Julia. Poderes de la perversión. Buenos Aires: Catálogos, 1988.

Laqueur, Thomas. La construcción del sexo. Cuerpo y género desde los griegos hasta Freud. Madrid: Cátedra, 1994.

Martínez, Ariel y Mora, Ana Sabrina. «Lo escénico como negatividad subversiva: ajenidad radical y performance trava sudaca en la voz de Susy Shock». Revista Brasileira de Estudos da Presença, 10:3 (2020), pp. 1-28. 
Preciado, Paul. Testo Yonqui. Madrid: Espasa-Calpe, 2008.

Rojas, Ulises. Diario de una marica mala. La Plata (Argentina): Pixel, 2019.

STryker, Susan. «(De)Subjugated Knowledges. An Introduction to Transgender Studies», en Stryker, Susan y Whittle, Stephen (eds.), The Transgender Studies Reader, New York: Routledge, 2006, pp. 1-18.

Viveiros de Castro, Eduardo. Metafísicas canibales Lineas de antropología postestructural. Buenos Aires: Katz, 2010.

WeIr, Allison. Sacrificial Logics: Feminist Theory and the Critique of Identity. New York: Routledge, 1996. 
